\title{
Investigation of the Dependence of Global Solar Radiation on Some Atmospheric Parameters Over Kano and Oyo-Nigeria
}

\author{
Inalegwu Emmanuel Ogwuche, Sombo T. \\ Department of Physics, Federal University of Agriculture, Makurdi, Nigeria \\ Email address: \\ inalegwu4free@yahoo.com (Inalegwu E. O.),jtsombo@gmail.com (Sombo T.)
}

\section{To cite this article:}

Inalegwu Emmanuel Ogwuche, Sombo T. Investigation of the Dependence of Global Solar Radiation on Some Atmospheric Parameters Over Kano and Oyo-Nigeria. Radiation Science and Technology. Vol. 3, No. 1, 2017, pp. 1-7. doi: 10.11648/j.rst.20170301.11

Received: January 29, 2017; Accepted: February 24, 2017; Published: March 6, 2017

\begin{abstract}
Some multi-linear regression equations were developed to investigate the dependence of global solar radiation on a combination of the following parameters: relative humidity, mean of daily temperature, ratio of maximum to minimum daily temperature, relative sunshine hour, rainfall, and the difference of monthly daily maximum and minimum temperature for Kano and Oyo-Nigeria for a span of 30 years (1981-2010). Using the Angstrom model as the base, ten (10) other regression equations were developed by modifying Angstrom equation. The results of statistical indicators: Coefficient of Determination $\left(\mathrm{R}^{2}\right)$, Mean Bias Error (MBE), Root Mean Square Error (RMSE) and Mean Percentage Error (MPE); performed on the model along with practical comparison of the estimated and observed data validate the excellent performance accuracy of the proposed model. The equations with the highest value of coefficient of determination $\mathrm{R}^{2}$ and least value of RMSE, MBE, and MPE are given as: $\mathrm{H} / \mathrm{H}_{\mathrm{o}}=0.351+0.556\left(\mathrm{~S} / \mathrm{S}_{\mathrm{o}}\right)-0.268(\mathrm{RH} / 100)$ and $\mathrm{H} / \mathrm{H}_{\mathrm{o}}=0.110+0.409\left(\mathrm{~S} / \mathrm{S}_{\mathrm{o}}\right)+0.152(\mathrm{RH} / 100)$ for Kano and Oyo respectively, where $\mathrm{S} / \mathrm{S}_{0}$ is the relative sunshine duration and $\mathrm{RH}$ is the relative humidity. The models can be used for estimating global solar radiation on horizontal surfaces for places with similar latitudes where radiation data are unavailable. Based on overall results, it was concluded that Sunshine duration and relative humidity are the most appropriate combination of climatic variables suitable for the estimation of global solar radiation in the study areas.
\end{abstract}

Keywords: Solar Radiation, Meteorological Parameters, Relative Humidity, Temperature, Relative Sunshine Duration, Statistical Indicator

\section{Introduction}

Solar radiation holds one of the relevant places among the diverse possible options of energy sources. It is the energy provided by the Sun. Nigeria receives ample solar energy that can be usefully exploited with an annual average daily solar radiation of about $5250 \mathrm{Wm}^{-2}$ day $^{-1}$ [1]. This alternates between $3500 \mathrm{Wm}^{-2} \mathrm{day}^{-1}$ at the coastal horizon and 7000 $\mathrm{Wm}^{-2} \mathrm{day}^{-1}$ at the northern periphery. The average amount of daily sunshine hours all-over the country is about 6.5 hours [1] and it has been found that there is an estimated 3,000 hours of annual sunshine [2]

Solar radiation data are fundamental for fabricating solar energy equipments. However, the instrument for measuring solar radiation is not easily available due to the expense and instrumentation involved [3]. Technology for measuring global solar radiation is uneconomical and has instrumental risk [4]. The poor coverage of the measurement shows that there is a need to practice theoretical methods for estimating solar radiation. Among the methods developed, are those based on empirical correlation using commonly measured meteorological elements. This method has attracted great attention owing to lower data requirement and computation cost [5].

The commonly used correlations for estimating solar radiation are majorly based on sunshine duration. But, sunshine duration is not as available as air temperature data at standard meteorological stations [6]. So it is meaningful to elaborate models that estimate solar radiation based on air temperature. Some studies were based on hourly solar radiation prediction using different meteorological parameters and the methods are claimed to perform well. Obviously, measured data is the best form of this knowledge. Unfortunately, there are very few meteorological stations that 
measure global solar radiation, especially in developing countries. For such stations where no measured data are available, the common practice is to estimate global solar radiation from other measured meteorological parameters like relative sunshine duration and temperature.

The quantity of solar radiation the Earth receives on its surface varies drastically as a function of changing atmospheric conditions as well as the changing position of the sun through the day [7]. The solar radiation reaching the earth's surface depends on the climatic condition of the specific site location, and this is essential for accurate prediction and design of a solar energy system [2]. Meteorological parameters such as relative humidity, rainfall, relative sunshine duration, mean temperature, soil temperature play an essential role in the radiative energy budget of the Earth and in the transfer of energy between the surface and atmosphere.

Information on global solar radiation received at any site (preferably gained over a long period) should be useful not only to the locality where the radiation data is collected but also for the wider world community [8].

Global solar radiation is an important parameter necessary for most ecological models and serves as input for different photovoltaic conversion systems; hence, it is of economic importance to renewable energy alternative. A global study of the world distribution of global solar radiation requires knowledge of the radiation data in various countries and for the purpose of worldwide marketing, the designers and manufacturers of solar equipment will need to know the average global solar radiation available in different and specific regions [9].

When global solar radiation is used to generate electrical energy for any specific site location, a provision should be made to forecast solar energy which will convert to electrical energy to recover the load demand, that is, the amount of solar energy for that place ought to be known. The solar radiation received at a particular location on the earth's surface must be known in order to evaluate the performance of any solar system at a given location. This energy depends on two main factors, namely the extraterrestrial solar radiation and the state of the atmosphere. The extraterrestrial solar radiation is the rate at which solar energy arrives on a horizontal surface at the top of the atmosphere. It varies according to the latitude of the location, the distance of the

$$
\mathrm{H}_{\mathrm{o}}=\frac{24}{\pi} \times 3.6 \times 10^{-3} \times \mathrm{I}_{\mathrm{sc}}\left\{1+0.033 \cos \left(360 \frac{\bar{D}}{365}\right)\right\} \cos \Phi \cos \delta \sin \omega+\omega \sin \Phi \sin \delta
$$

where, $\bar{D}$ is the Julian day number, $\mathrm{I}_{\mathrm{sc}}$ is the solar constant in $\mathrm{MJm}^{-2} \mathrm{day}^{-1}$. The value of $\mathrm{I}_{\mathrm{sc}}$ to be used in this work is $1367 \mathrm{wm}^{-2}$,

$\phi$ is the latitude of the location, $\delta$ is the declination angle. The value of declination can be found from the equation of [13] as:

$$
\delta=23.45 \sin \left(360 \frac{248+\bar{D}}{365}\right)
$$

Earth from the sun, and the time of the year. On any particular day, it varies from zero at sunrise to a maximum at noon and back at zero at sunset [10].

\section{Methodology}

The global solar radiation, sunshine hour, rainfall, relative humidity, minimum and maximum air temperature data for Oyo $\left(8.11^{\circ} \mathrm{N}, 3.42^{\circ} \mathrm{E}\right.$, and $\left.304 \mathrm{~m}\right)$ and Kano $\left(12.2^{\circ} \mathrm{N}, 8.30^{\circ} \mathrm{E}\right.$, $488 \mathrm{~m})$ were obtained from the International Institute for Tropical Agriculture (IITA), Ibadan. The data spanned for a period of thirty years (1981-2010). The extraterrestrial solar radiation $\left(\mathrm{H}_{\mathrm{o}}\right)$, relative sunshine duration $\left(\mathrm{S} / \mathrm{S}_{\mathrm{o}}\right)$, ratio of minimum to maximum temperature $\left(\frac{T_{\min }}{T_{\max }}\right)$, relative humidity $(\mathrm{R})$, rainfall $(\mathrm{RF})$, monthly mean daily temperature $\left(T_{\text {mean }}\right)$, and the difference between maximum and minimum daily temperature $\left(\mathrm{T}_{\max }-\mathrm{T}_{\min }\right)$ were used as input parameters for the estimation of global solar radiation are recorded in Table 1 for Kano while that of Oyo is recorded in Tables 2.

\subsection{Data Analysis}

A lot of climatic parameters have been used in developing empirical relations for predicting the monthly average global solar radiation. Among the existing correlations, the following relation is the generally accepted modified form of the Angstrom-type regression equation, relating the monthly average daily global radiation to the average daily sunshine hours and is given as [11]

$$
\frac{H_{m}}{H_{0}}=\mathrm{a}+\mathrm{b}
$$

where $\mathrm{H}_{\mathrm{m}}$ is the monthly average daily global radiation on a horizontal surface $\left(\mathrm{MJm}^{-2} \mathrm{day}^{-1}\right) \cdot \mathrm{H}_{0}$ is the monthly average daily extraterrestrial radiation on a horizontal surface $\left(\mathrm{MJm}^{-}\right.$

${ }^{2}$ day $\left.^{-1}\right) . \bar{S}$ is the monthly average daily number of hours of bright sunshine. $S_{0}$ is the monthly average daily maximum number of hours of possible sunshine (or day length) and "a" and " $b$ " are regression constants to be determined. The extraterrestrial solar radiation on a horizontal surface $H_{o}$ is given by [12] as:

The maximum possible daily, also called the length of day is given by [14] as sunshine duration $S_{0}$ is given by

$$
\bar{S}_{0}=\left(\frac{12}{15}\right) \omega_{\mathrm{s}}
$$

Where $\omega_{\mathrm{s}}$ is the sunset hour angle given by [15] as:

$$
\omega_{\mathrm{s}}=\cos ^{-1}(-\tan \Phi \tan \delta)
$$


Equations $1-5$ were used in the analyses of the meteorological data in this work.

\subsection{Two Variable Equations for Kano}

The monthly mean daily global solar radiation calculated using equations (6)-(10) were recorded as model 1-5 is shown in Table 1 while variations of the measured and estimated global solar radiation are presented in Figures 1-5.

The correlations to which the measured data were fitted are as follows:

$$
\begin{gathered}
\frac{H_{e s t}}{H_{o}}=1.553-0.016\left(T_{\max }-T_{\min }\right)-1.117(R H) \\
\frac{H_{e s t}}{H_{o}}=0.543+0.001\left(T_{\max }-T_{\min }\right)-0.010(R H) \\
\frac{H_{e s t}}{H_{o}}=0.351+0.556\left(\frac{S}{S_{o}}\right)-0.268(R H) \\
\frac{H_{e s t}}{H_{o}}=-0.294+0.698\left(\frac{S}{S_{o}}\right)+0.012\left(T_{\text {mean }}\right) \\
\frac{H_{e s t}}{H_{o}}=0.348+0.650\left(\frac{S}{S_{o}}\right)-0.393\left(\frac{T_{\min }}{T_{\text {max }}}\right)
\end{gathered}
$$

\subsection{Two Variable Equations for Oyo}

The monthly mean daily global solar radiation calculated using equations (11)-(15) were recorded as model 6-10 in Table 2 while variations of the measured and estimated global solar radiation are presented in Figures 6-10.

The correlations to which the measured data were fitted are as follows:

$$
\begin{gathered}
\frac{H_{e s t}}{H_{o}}=-1.429+0.073+\left(T_{\max }-T_{\min }\right)+1.588(R H) \\
\frac{H_{e s t}}{H_{o}}=0.184+0.024\left(T_{\max }-T_{\min }\right)+0.007(R H) \\
\frac{H_{e s t}}{H_{o}}=0.110+0.409\left(\frac{S}{S_{o}}\right)+0.152(R H)
\end{gathered}
$$

$$
\begin{aligned}
& \frac{H_{e s t}}{H_{o}}=0.080+0.276\left(\frac{S}{S_{o}}\right)+0.008\left(T_{\text {mean }}\right) \\
& \frac{H_{e s t}}{H_{o}}=0.035+0.419\left(\frac{S}{S_{o}}\right)+0.257\left(\frac{T_{\min }}{T_{\max }}\right)
\end{aligned}
$$

where $\mathrm{T}_{\text {mean }}$ is the mean temperature $\left({ }^{\circ} \mathrm{C}\right), \mathrm{T}_{\max }$ is the monthly maximum daily temperature $\left({ }^{\circ} \mathrm{C}\right), \mathrm{T}_{\min }$ is the monthly minimum daily temperature $\left({ }^{\circ} \mathrm{C}\right), \mathrm{H}_{\mathrm{est}}$ is estimated global solar radiation on a horizontal Plane $\left(\mathrm{MJm}^{-2} \mathrm{day}^{-1}\right), \mathrm{RF}$ is rainfall $(\mathrm{mm}), \mathrm{RH}$ is Relative Humidity $(\%), \mathrm{H}_{\mathrm{o}}$ is extraterrestrial solar radiation $\left(\mathrm{MJm}^{-2} \mathrm{day}^{-1}\right),\left(\mathrm{S} / \mathrm{S}_{\mathrm{o}}\right)$ is the relative sunshine duration $(\mathrm{hr})$

\subsection{Statistical Analysis}

The accuracy of the estimated values was tested by calculating the RMSE (Root Mean Square Error), MBE (Mean Bias Error) and MPE (Mean Percentage Error). The expressions for RMSE $\left(\mathrm{MJ} / \mathrm{m}^{2}\right), \operatorname{MBE}\left(\mathrm{MJ} / \mathrm{m}^{2}\right)$ and MPE (\%) as stated according to [16] are given as follows;

$$
\begin{gathered}
R M S E=\left\{\left(\sum\left(H_{\text {pred }}-H_{o b s}\right)^{2}\right) / n\right\}^{\frac{1}{2}} \\
M B E=\left[\sum\left(H_{\text {pred }}-H_{o b s}\right)\right] / n \\
M P E=\left[\sum\left(\frac{H_{o b s}-H_{\text {pred }}}{H_{o b s}} \times 100\right)\right] / n
\end{gathered}
$$

where $\mathrm{H}_{\text {pred }}$ and $\mathrm{H}_{\mathrm{obs}}$ are the predicted (estimated) and observed (measured) values respectively and $n$ is the total number of observations. RMSE and MBE statistical indicators are frequently used in comparing the models of

\begin{tabular}{|c|c|c|c|c|c|c|c|c|}
\hline Month & $\mathbf{T}_{\max }-\mathbf{T}_{\min }\left({ }^{\circ} \mathrm{C}\right)$ & $\frac{T_{\min }}{T_{\max }}\left({ }^{\circ} \mathbf{C}\right)$ & $\mathbf{T}_{\text {mean }}\left({ }^{\circ} \mathbf{C}\right)$ & $\mathrm{H}_{\mathrm{m}}\left(\mathrm{MJ}^{-2} \mathrm{mday}^{-1}\right)$ & $\mathrm{H}_{0}\left(\mathrm{MJ}^{-2} \mathrm{mday}^{-1}\right)$ & $\mathbf{S}_{\text {o(hours) }}$ & $\frac{S}{S_{o}}$ (hours) & $\mathrm{RH}_{\text {mean }}(\%)$ \\
\hline Jan & 13.910 & 0.631 & 29.280 & 17.410 & 30.940 & 11.368 & 0.710 & 68.64 \\
\hline Feb & 13.748 & 0.633 & 30.550 & 19.060 & 33.790 & 11.619 & 0.713 & 67.67 \\
\hline Mar & 12.977 & 0.653 & 30.870 & 19.660 & 36.520 & 11.931 & 0.679 & 71.82 \\
\hline Apr & 11.902 & 0.671 & 30.200 & 19.630 & 38.020 & 12.273 & 0.677 & 75.93 \\
\hline May & 11.770 & 0.670 & 29.740 & 19.390 & 38.020 & 12.563 & 0.636 & 78.46 \\
\hline Jun & 11.532 & 0.672 & 29.310 & 18.340 & 37.640 & 12.705 & 0.607 & 80.13 \\
\hline Jul & 9.756 & 0.707 & 28.540 & 17.370 & 37.660 & 12.641 & 0.586 & 82.46 \\
\hline
\end{tabular}
solar radiation predictions. The test RMSE provides information on the short-term performance of the studied models as it allows a term-by-term comparison of the actual deviation between the calculated value and the measured value. [14], [17] and [18] have recommended that a zero value for MBE is ideal and low RMSE is desirable. The use of RMSE and MBE statistical indicator is not adequate for the evaluation of models performance thus decisions were made that MPE be used in addition to RMSE and MBE to give more reliable result.

\section{Results}

Table 1. MONTHLY MEan input parameters and measured global solar radiation for Kano. 


\begin{tabular}{|c|c|c|c|c|c|c|c|c|}
\hline Month & $\mathbf{T}_{\max }-\mathbf{T}_{\min }\left({ }^{\circ} \mathbf{C}\right)$ & $\frac{T_{\min }}{T_{\max }}\left({ }^{\circ} \mathbf{C}\right)$ & $\mathbf{T}_{\text {mean }}\left({ }^{\circ} \mathbf{C}\right)$ & $\mathrm{H}_{\mathrm{m}}\left(\mathrm{MJ}^{-2} \mathrm{mday}^{-1}\right)$ & $\mathrm{H}_{0}\left(\mathrm{MJ}^{-2} \mathrm{mday}^{-1}\right)$ & $\mathbf{S}_{\text {o(hours) }}$ & $\frac{S}{S_{o}}$ (hours) & $\mathbf{R H}_{\text {mean }}(\%)$ \\
\hline Aug & 9.383 & 0.716 & 28.390 & 16.350 & 37.790 & 12.397 & 0.573 & 83.58 \\
\hline Sep & 10.207 & 0.700 & 28.880 & 16.950 & 36.870 & 12.065 & 0.638 & 82.17 \\
\hline Oct & 10.439 & 0.695 & 20.050 & 18.250 & 34.450 & 11.720 & 0.698 & 80.23 \\
\hline Nov & 10.727 & 0.690 & 29.200 & 18.660 & 31.520 & 11.433 & 0.749 & 74.21 \\
\hline Dec & 12.066 & 0.656 & 29.080 & 16.580 & 29.990 & 11.297 & 0.751 & 70.64 \\
\hline
\end{tabular}

Table 2. Monthlymean input parameters and measured global solar radiation for Oyo.

\begin{tabular}{|c|c|c|c|c|c|c|c|c|}
\hline Month & $\mathbf{T}_{\max }-\mathbf{T}_{\min }$ & $\frac{T_{\min }}{T_{\max }}$ & $\mathbf{T}_{\text {mean }}\left({ }^{\circ} \mathbf{C}\right)$ & $\mathrm{H}_{\mathrm{m}}\left(\mathrm{MJ}^{-2} \mathrm{mday}^{-1}\right)$ & $\mathrm{H}_{0}\left(\mathrm{MJ}^{-2} \mathrm{mday}^{-1}\right)$ & $\mathbf{S}_{\mathbf{0} \text { (hours) }}$ & $\frac{S}{S_{o}}$ (hours) & $\mathrm{RH}_{\text {Mean }}(\%)$ \\
\hline Jan & 12.407 & 0.624 & 26.750 & 14.380 & 32.860 & 11.584 & 0.5774 & 61.34 \\
\hline Feb & 12.508 & 0.641 & 28.570 & 16.370 & 35.200 & 11.749 & 0.5973 & 61.83 \\
\hline Mar & 11.040 & 0.678 & 28.810 & 17.230 & 37.170 & 11.955 & 0.5947 & 68.12 \\
\hline Apr & 9.641 & 0.706 & 27.990 & 17.240 & 37.800 & 12.180 & 0.5575 & 75.05 \\
\hline May & 8.798 & 0.720 & 27.020 & 16.950 & 37.100 & 12.371 & 0.5409 & 78.28 \\
\hline Jun & 7.892 & 0.737 & 26.020 & 15.780 & 36.400 & 12.464 & 0.4696 & 80.09 \\
\hline Jul & 6.407 & 0.773 & 25.020 & 13.010 & 36.570 & 12.423 & 0.3045 & 82.67 \\
\hline Aug & 6.052 & 0.782 & 24.680 & 11.920 & 37.260 & 12.261 & 0.2292 & 83.69 \\
\hline Sep & 7.102 & 0.754 & 25.360 & 14.060 & 37.180 & 12.041 & 0.3330 & 81.59 \\
\hline Oct & 8.069 & 0.732 & 26.110 & 15.320 & 35.600 & 11.816 & 0.4887 & 79.60 \\
\hline Nov & 9.506 & 0.703 & 27.190 & 15.800 & 33.300 & 11.627 & 0.6403 & 72.27 \\
\hline Dec & 11.200 & 0.654 & 26.770 & 14.210 & 32.030 & 11.537 & 0.6376 & 66.51 \\
\hline
\end{tabular}

Table 3. Observed and predicted global solar radiation for models comprising of two variables for Kano station.

\begin{tabular}{|c|c|c|c|c|c|c|}
\hline Months & $\mathrm{H}_{M}\left(\mathrm{MJm}^{-2} \mathrm{day}^{-1}\right)$ & Model $1\left(\mathrm{MJm}^{-2} \mathrm{day}^{-1}\right)$ & Model $2\left(\mathrm{MJm}^{-2} \mathrm{day}^{-1}\right)$ & Model $3\left(\mathrm{MJm}^{-2} \mathrm{day}^{-1}\right)$ & Model $4\left(\mathrm{MJm}^{-2}\right.$ day $\left.^{1}\right)$ & $\begin{array}{l}\text { Model 5 } \\
\left(\text { MJm }^{-2} \text { day }^{-1}\right)\end{array}$ \\
\hline Jan & 17.41 & 17.43 & 17.23 & 17.37 & 17.09 & 17.36 \\
\hline Feb & 19.06 & 19.50 & 18.82 & 19.12 & 19.25 & 19.01 \\
\hline Mar & 19.66 & 19.82 & 20.31 & 19.56 & 20.08 & 19.45 \\
\hline Apr & 19.63 & 19.57 & 20.91 & 19.90 & 20.54 & 19.63 \\
\hline May & 19.39 & 18.58 & 19.99 & 18.77 & 19.26 & 18.94 \\
\hline June & 18.34 & 17.80 & 18.67 & 17.81 & 18.12 & 18.02 \\
\hline Aug & 16.35 & 17.74 & 16.16 & 16.82 & 16.87 & 16.58 \\
\hline Sep & 16.95 & 17.41 & 17.97 & 17.87 & 18.34 & 17.97 \\
\hline Oct & 18.25 & 16.87 & 18.78 & 18.02 & 18.66 & 18.20 \\
\hline Nov & 18.66 & 17.40 & 17.43 & 17.91 & 18.25 & 17.77 \\
\hline Dec & 16.58 & 17.12 & 16.64 & 17.35 & 17.37 & 17.35 \\
\hline
\end{tabular}

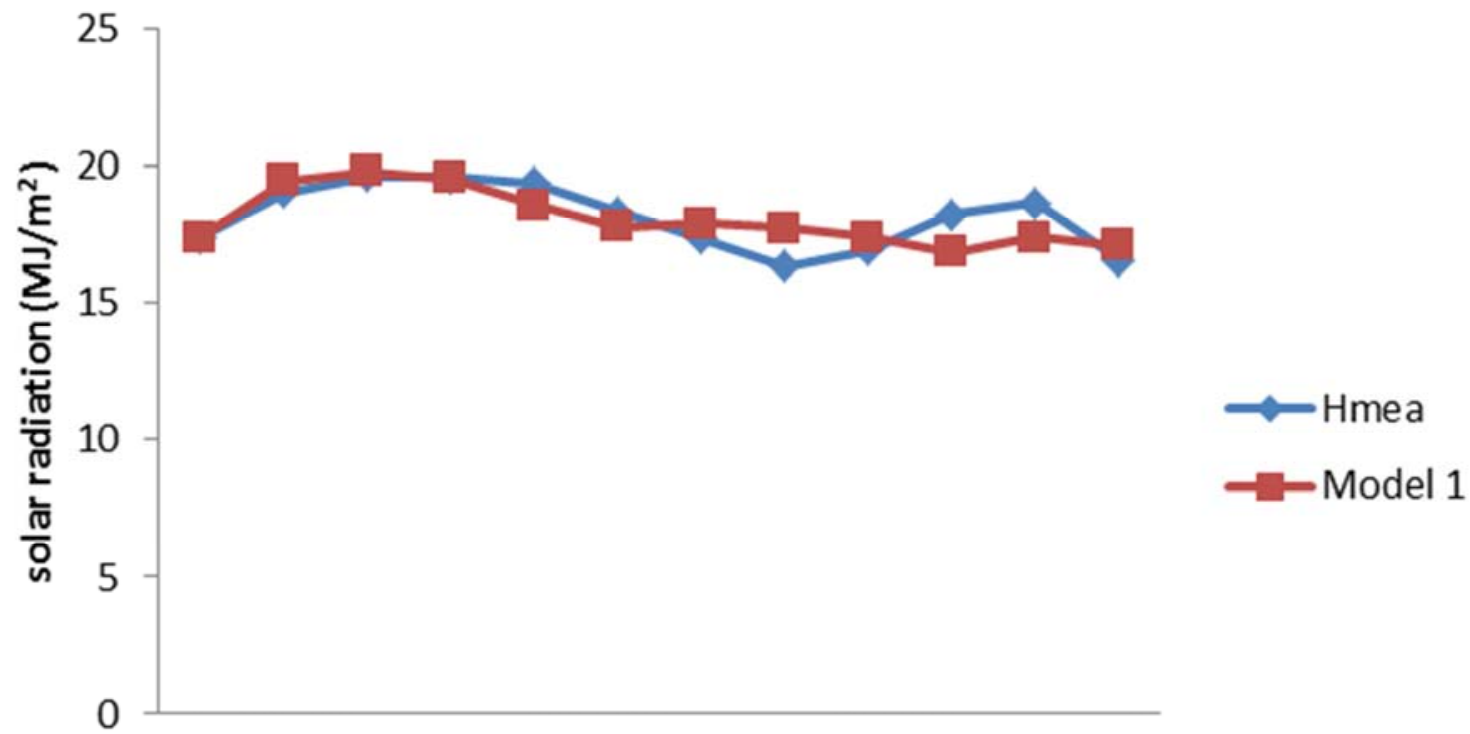

Jan Feb Mar Apr May Jun Jul Aug Sep Oct Nov Dec

Months

Figure 1. Comparison between measured and predicted global solar radiation using model 1. 


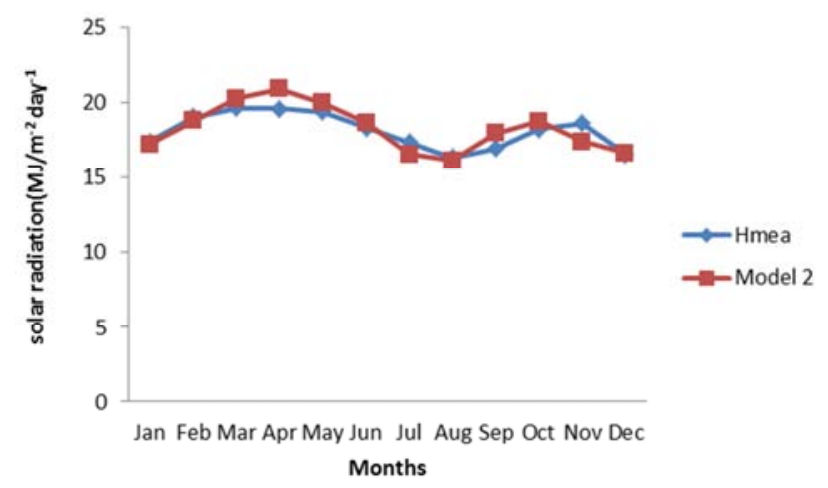

Figure 2. Comparison between measured and predicted global solar radiation using model 2.

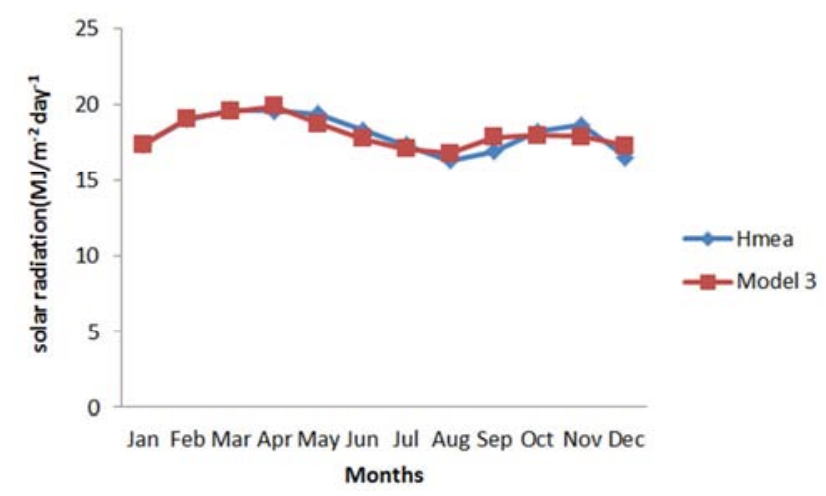

Figure 3. Comparison between measured and predicted global solar radiation using model 3.

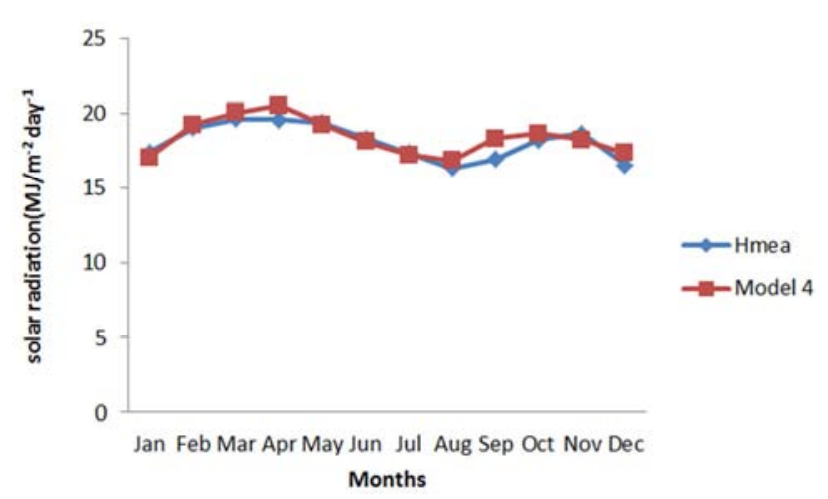

Figure 4. Comparison between measured and predicted global solar radiation using model 4.

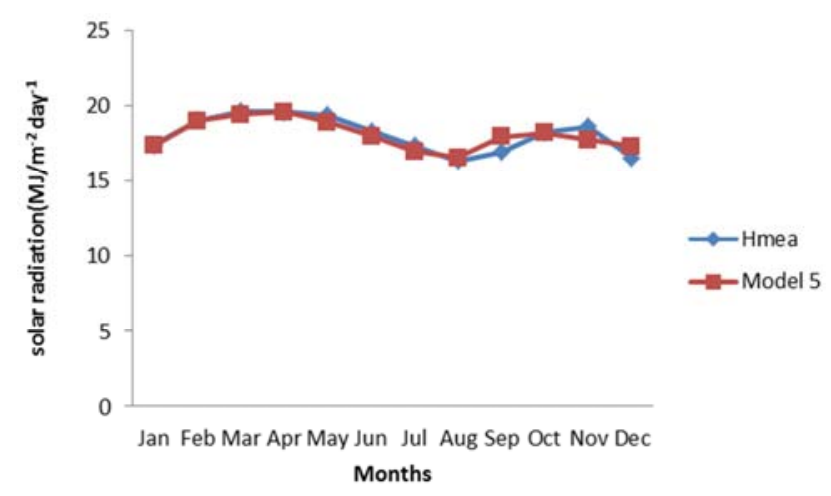

Figure 5. Comparison between measured and predicted global solar radiation using model 5 .

Table 4. Observed and predicted global solar radiation for models comprising of two variables for Oyo station.

\begin{tabular}{|c|c|c|c|c|c|c|}
\hline Months & $\mathrm{H}_{\mathrm{M}}\left(\mathrm{MJm}^{-2} \mathrm{day}^{-1}\right)$ & Model $6\left(\mathrm{MJm}^{-2} \mathrm{day}^{-1}\right)$ & Model $7\left(\mathrm{MJm}^{-2} \mathrm{day}^{-1}\right)$ & Model $8\left(\mathrm{MJm}^{-2} \mathrm{day}^{-1}\right)$ & Model $9\left(\mathrm{MJm}^{-2} \mathrm{day}^{-1}\right)$ & $\begin{array}{l}\text { Model } 10 \\
\left(\mathrm{MJm}^{-2} \mathrm{day}^{-1}\right)\end{array}$ \\
\hline Jan & 14.38 & 14.82 & 15.86 & 14.43 & 14.89 & 14.37 \\
\hline Feb & 16.37 & 16.41 & 17.24 & 15.78 & 16.67 & 15.83 \\
\hline Mar & 17.23 & 17.05 & 17.27 & 16.98 & 17.64 & 17.04 \\
\hline April & 17.24 & 17.63 & 16.76 & 17.09 & 17.31 & 17.03 \\
\hline May & 16.95 & 16.94 & 15.97 & 16.70 & 16.51 & 16.58 \\
\hline June & 15.78 & 15.24 & 15.21 & 15.43 & 15.22 & 15.34 \\
\hline Aug & 11.92 & 12.71 & 13.30 & 12.34 & 12.69 & 12.37 \\
\hline Sept & 14.06 & 14.31 & 15.14 & 13.76 & 13.94 & 13.71 \\
\hline Oct & 15.32 & 15.10 & 14.81 & 15.34 & 15.09 & 15.24 \\
\hline Nov & 15.80 & 13.75 & 13.91 & 16.06 & 15.80 & 16.10 \\
\hline Dec & 14.21 & 14.25 & 14.57 & 15.12 & 15.06 & 15.06 \\
\hline
\end{tabular}

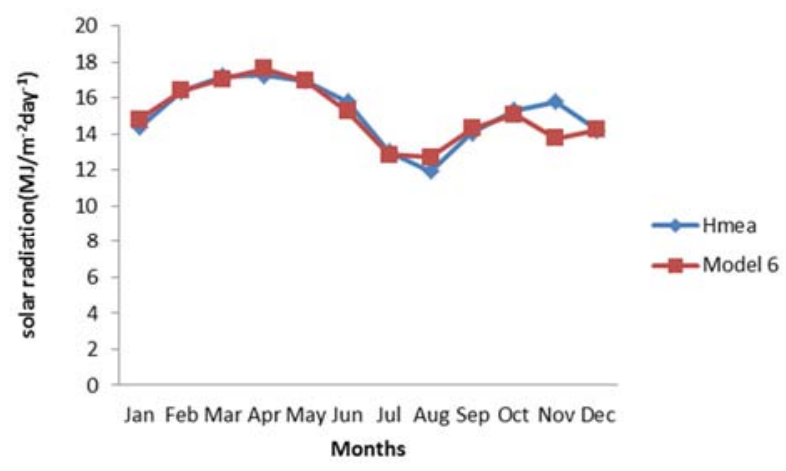

Figure 6. Comparison between measured and predicted global solar radiation using model 6.

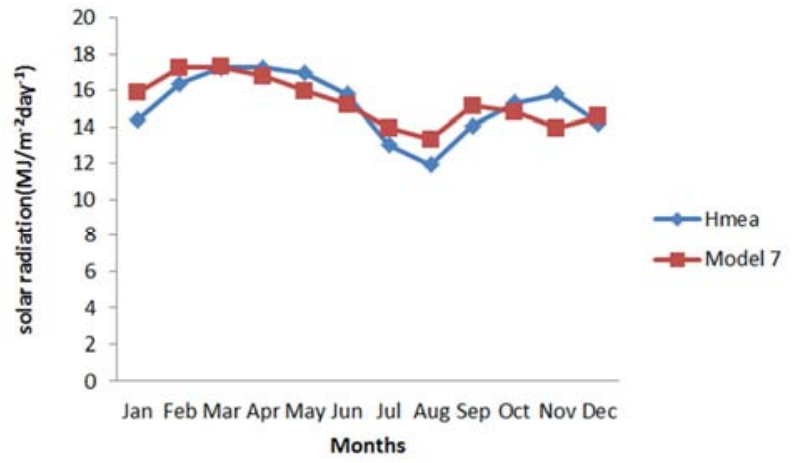

Figure 7. Comparison between measured and predicted global solar radiation using model 7. 


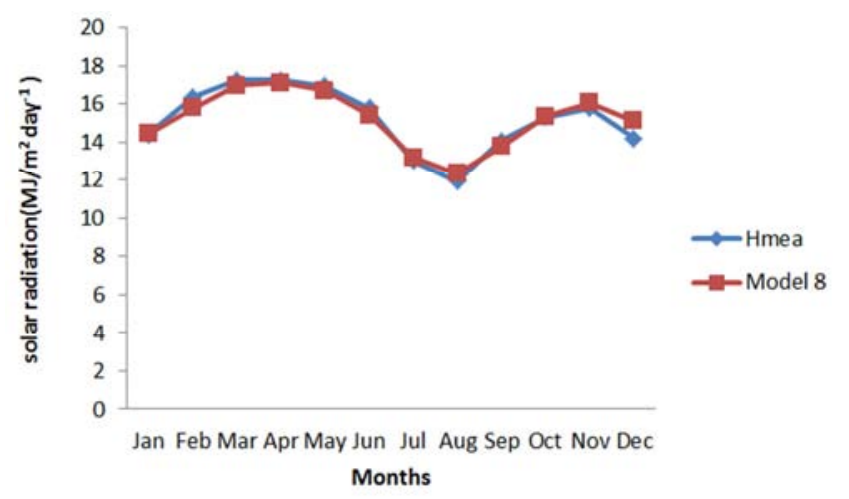

Figure 8. Comparison between measured and predicted global solar radiation using model 8.

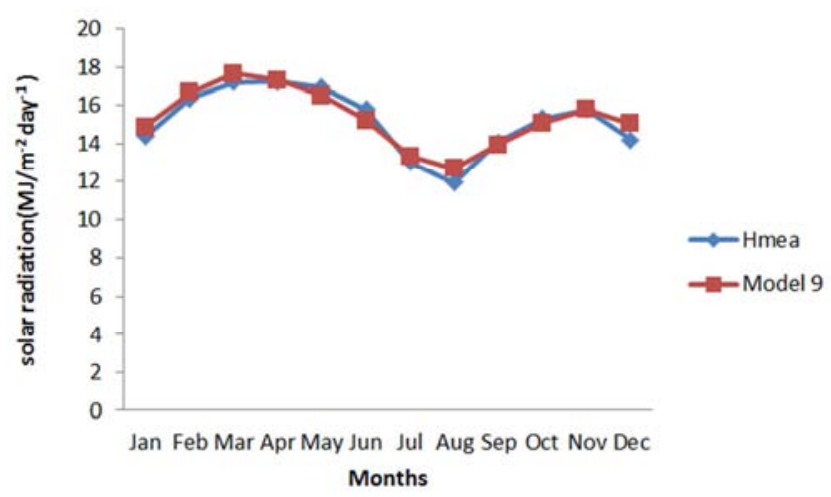

Figure 9. Comparison between measured and predicted global solar radiation using model 9.

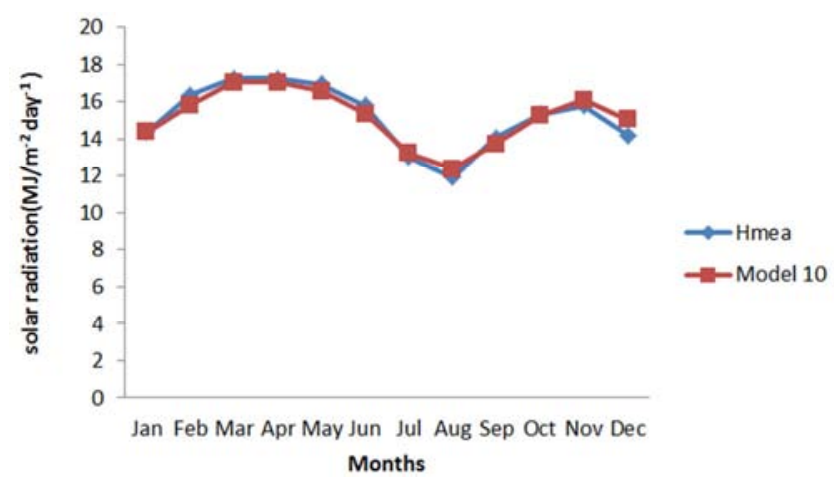

Figure 10. Comparison between measured and predicted global solar radiation using model 10.

Table 5. Models and Statistical indicators for Kano.

\begin{tabular}{llllll}
\hline Model & R & $\mathbf{R}^{2}$ & MBE & RMSE & MPE \\
\hline 1 & 0.878 & 0.771 & -0.041 & 0.141 & 0.019 \\
2 & 0.909 & 0.827 & 0.153 & 0.531 & -0.070 \\
3 & 0.949 & 0.900 & -0.002 & 0.006 & 0.001 \\
4 & 0.946 & 0.894 & 0.283 & 0.981 & -0.130 \\
5 & 0.948 & 0.898 & -0.033 & 0.113 & 0.015 \\
\hline
\end{tabular}

Table 6. Models and Statistical Indicators for Oyo.

\begin{tabular}{llllll}
\hline Model & $\mathbf{R}$ & $\mathbf{R}^{2}$ & MBE & RMSE & MPE \\
\hline 6 & 0.904 & 0.818 & -0.100 & 0.165 & 0.055 \\
7 & 0.789 & 0.623 & 0.141 & 0.488 & -0.077 \\
8 & 0.970 & 0.941 & -0.004 & 0.014 & 0.002 \\
9 & 0.965 & 0.931 & 0.155 & 0.537 & -0.085 \\
10 & 0.969 & 0.938 & -0.031 & 0.107 & 0.017 \\
\hline
\end{tabular}

\section{Discussion}

\subsection{Estimation of Solar Radiation for Kano Using Two Variables}

Figure 1 shows that in the rainy season, the lowest solar radiation was obtained in October while the lowest values for global solar radiation (Fig. 2 - 5) was obtained in August for both the measured and estimated global solar radiation (probably due to clouds which permeated the sky). In the dry season, the highest value of solar radiation was measured in March for the measured and estimated value for model 1 and April for models 2-5. The lowest value for both measured and estimated solar radiation fell between December and January (probably due to harmattan dust which perturbed solar radiation at the time).

Of the five models, model 3 had the best coefficient of determination $\left(\mathrm{R}^{2}\right)$ of $90.9 \%$ suggesting a good correlation and reliable estimate of the regression constants. Overall, model 3 produced more accurate estimates than the existing 4 models. This can be seen from the fact that Figure 3 (model 3) has smaller values for MBE, RMSE and MPE compared with the other models. This is in agreement with [17], [18] that a zero value of MBE is ideal and low RMSE and MPE is desirable.

\subsection{Estimation of Solar Radiation for Oyo Using Two Variables}

Table 6 contains summaries of the models under consideration. It is clear that the statistical indicator of coefficient of determination $\mathrm{R}^{2}$, MBE, RMSE and MPE vary from one model to another. In general, model 6, 8, 9 and model 10 having a correlation coefficient (0.904-0.970) are high for these models. This implies that, there are statistically significant relationships between the measured and the estimated values. This is further demonstrated by high value of coefficient of determination $\mathrm{R}^{2}(0.818-0.941)$ across the variables. The lowest RMSE value of 0.014 showed that model 8 has the best correlation between estimated and measured global solar radiation.

\section{Conclusion and Recommendation}

Multiple regression techniques have been employed in this study to develop several correlation equations to describe the dependence of global solar radiation on some atmospheric data for Kano and Oyo, Nigeria.

The values of statistical indices (MBE, RMSE, and MPE) obtained in this research work show that the difference between the estimated and the measured global solar radiation is not much, implying that the models used in this research to estimate the global solar radiation in these cities are validated.

The result shows that model 3 and 8 which are the equations with the highest $\mathrm{R}^{2}$ give the best result for Kano and Oyo respectively when considering the error terms (MBE, RMSE, and MPE). Hence the multiple regression 
equation can be employed for the purpose of estimating global solar radiation for Kano and Oyo-Nigeria and for locations that have the same climate and latitude as both locations. The model for Kano is:

$$
\frac{H_{e s t}}{H_{o}}=0.351+0.556 \frac{S}{S_{o}}-0.268 \frac{R H}{100}
$$

Similarly, the model for Oyo is

$$
\frac{H_{e s t}}{H_{o}}=0.110+0.409 \frac{S}{S_{o}}+0.152 \frac{R H}{100}
$$

The maximum and minimum values of monthly average global solar radiation for Kano-Nigeria are found to be $19.66 \mathrm{MJm}^{-2} \mathrm{day}^{-1}$ and $16.35 \mathrm{MJm}^{-2} \mathrm{day}^{-1}$ respectively while that of Oyo-Nigeria is found to be $17.24 \mathrm{MJm}^{-2}$ days- ${ }^{1}$ and $11.92 \mathrm{MJm}^{-2}$ days- ${ }^{1}$ respectively.

Since facilities for recording global solar radiation data are not easily available probably because of poor maintenance culture or lack of trained personnel to take measurements or delay in repair in case of instrument failure or malfunction, these equations can be used to estimate global solar radiation in these areas and their environs with similar climatic conditions.

\section{References}

[1] Chineke, T. C. and Igwiro, E. C. (2008): Urban and rural electrification-enhancing the energy sector in Nigeria using photovoltaic technology. African journal science and tech. Vol. 9, Pp. 102-108.

[2] Burari and Sambo (2001). Model for the prediction of global solar radiation for Bauchi using meteorological data. Nigeria journal of renewable energy Vol. 91 Pp 30-33.

[3] El-Sebaii, A. A, Al-Hazmi, F. S. Al-Ghamdi, A. A. Yaghmour, S. J.(2010). Global, direct and diffuse solar radiation on horizontal and tilted surfaces in Jeddah, Saudi Arabia. Applied Energy.87 (2):568-576.

[4] Alam M. S. Saha, S. K. Chowdhury, M. A. Saifuzzaman, M. and Rahman, M. (2005). Simulation of solar radiation systems. American Journal of Applied Sciences. 2 (4): 751758.

[5] Liu, X. Mei, X. and Li, Y. (2009). Evaluation of temperature based models in China. Agricultural and Forest Meteorology. 149 (9): 1433-1446.

[6] Rahimikhoob, A. (2010). Estimating global solar radiation using artificial neural network and air temperature data in a semi-arid environment. Renewable Energy. 35 (9): 2131-2135.

[7] Falayi, E. O. (2013). The Impact of Cloud Cover, Relative Humidity, Temperature and Rainfall on Solar Radiation in Nigeria.

[8] Massaquoi, J. G. M. (1988). Global solar radiation in Sierra Leone (West Africa). Solar Wind Technology.5, 281 (283).

[9] Ibrahim S. M. A (1985). Nigeria Journal on Solar Energy 35 (2): $185-188$.

[10] Liou, (1980); Introduction to Atmospheric Radiation. Academy press New York.

[11] Angstrom, A. J. (1924). Solar and terrestrial radiation. Q. J Roy Met. Soc. 50: 121-126.

[12] Duffie J. A.; Beckmann W. A. (2013). Solar engineering of thermal processes $3{ }^{\text {rd }}$ Edition, John Wiley, New Jersey.

[13] Cooper, P. I. (1969). The absorption of solar radiation in solar stills. Solar energy, 12 (3): 31.

[14] Igbal, M. (1983). An introduction to solar radiation. Academy press, New York.

[15] Fayadh, M. A. and Ghazi, A. (1983). Estimation of global solar radiation in horizontal surfaces over Egypt. J. solids, 28: 166-172.

[16] El-sebaii, A. A. and Trabea, A. A. (2005). Estimation of global solar radiation on horizontal surfaces over Egypt. J. Solids, 28: 166-172.

[17] Almorox, J. (2005). Estimating global solar radiation from common meteorological data in Aranjuez, Spain. 35. 53-64.

[18] Che, H. Z. Shi, G. Y. Zhang, X. Y. Zhao, J. Q. and Li, Y. (2007). Analysis of sky condition using 40 years record of solar radiation data in china. Theoretical and applied climatology. 89: 83-94. 